\title{
SOLATION OF CHELIDONINE AS AN ANALGESIC COMPOUND FROM CHELIDONIUM MAJUS L.
}

\author{
ANALJEZİK ETKİLİ BİLEŞİK OLARAK CHELİDONIUM MAJUS'TAN KELIDONIN \\ İOLASYONU
}

\author{
Gülçin SALTAN ÇiTOĞLU ${ }^{1}$ ， Hanefi ÖZBEK ${ }^{2}$ ， Özlem BAHADIR ACIKARA ${ }^{1}$, \\ Eszter BAITZ GACS ${ }^{3}$ \\ ${ }^{1}$ Ankara University, Faculty of Pharmacy, Department of Pharmacognosy, 06100 Tandoğan, \\ Ankara, TURKEY \\ ${ }^{2}$ Ministry of Health of Turkey General Directorate of Pharmaceuticals and Pharmacy, 06060 \\ Ankara, TURKEY \\ ${ }^{3}$ Institute of Chemistry, CRC Hungarian Academy of Sciences, H-135 Budapest, HUNGARY
}

\begin{abstract}
In this study the analgesic activity of chelidonine which was isolated from the aerial parts of Chelidonium majus (Papaveraceae), was investigated by using tail-flick test. Chelidonine is one of the main alkaloid in the aerial parts of C. majus. Isolation of chelidonine was performed by using chromatographic techniques. Spectroscopic $\left({ }^{1} H-N M R,{ }^{13} C-N M R\right)$ and physical (melting point) methods were used for structure elucidation of the isolated compound. Analgesic activity of the compound was evaluated by using tail-flick test on mice at $5 \mathrm{mg} / \mathrm{kg}$ dose. Chelidonine produced higher analgesic activity than aspirine at $90^{\text {th }}$ minute. However equivalent analgesic activity to aspirine was observed at $150^{\text {th }}$ minute with chelidonine treatment.

Key words: Chelidonium majus, Papaveraceae, Chelidonine, Analgesic activity, Tail-flick test

Bu çalışmada Chelidonium majus'un (Papaveraceae) toprak üstü kısımlarından izole edilen kelidoninin analjezik aktivitesi kuyruk kaldırma testi kullanılarak araştırılmıştır. Kelidonin, C. majus'un toprak üstü kısımlarında bulunan major alkaloitlerden birisidir. Kelidonin izolasyonu kromatografik teknikler kullanılarak gerçekleştirilmiştir. İzole edilen bileşiğin yapısı spektroskopik $\left({ }^{1} H-N M R,{ }^{13} C\right.$-NMR) ve fiziksel (erime noktası) yöntemler kullanılarak aydınlatılmıştır. Bileşiğin analjezik aktivitesi $5 \mathrm{mg} / \mathrm{kg}$ dozda fareler üzerinde kuyruk kaldırma testi kullanılarak değerlendirilmiştir. Kelidoninin bu dozdaki analjezik aktivitesinin 90. dakikada aspirinden daha yüksek olduğu, 150. dakikada ise aspirine eşit bir analjezik aktivite gösterdiği tespit edilmiştir.
\end{abstract}

Anahtar kelimeler: Chelidonium majus, Papaveraceae, Kelidonin, Analjezik Aktivite, Tail-flik testi 


\section{INTRODUCTION}

Chelidonium majus L. (Papaveraceae) is an important medicinal herb used in traditional medicine throughout the world. It is used for the treatment of different illnesses such as gastric ulcer, gastric cancer, oral infections, liver diseases and general pains (1-5). Chelidonii herba which is the commercial drug, consists of the dried aerial parts harvested when blooming has been described in several pharmacopoeias. There are also several OTC preparations of Chelidonium majus which are using for their cholagogue and choleretic activities in European markets (5).

In Turkish folk medicine Chelidonium majus is known as kırlangıç otu and it is widely used for its diuretic, choleretic, hipnotic properties. The aerial parts and latex of the plant are used as a remedy for blister rashes, scabies and warts in Turkey (6-7).

Earlier studies have demonstrated that Chelidonium majus exhibited many biological activities such as antiviral, antibacterial, antifungal (2-4), anti-inflammatory cytotoxic, antitumor and spasmolytic (6-9). The main active constituents of Chelidonium majus are the alkaloids; chelidonine, chelerythrine, coptisine, sanguinarine and berberine $(5,6)$. Among them chelidonine and protopine exhibited anti-tumor activity, protoberberine showed antibacterial and antiviral activity, sanguinarine and chelerythrine have anti-inflammatory activity and recent studies 8 hydroxydihydro derivatives of sanguinarine and chelerythrine exerted acetylcholinesterase inhibitory activity $(4,9)$.

In our earlier study, analgesic and hepatoprotective effects of the plant were evaluated. We found that Chelidonium majus had analgesic activity but no hepatoprotective activity (7). The current investigation was carried out to evaluate the analgesic activity of chelidonine as one of the main component of C. majus. Methanol extract of the aerial parts of the plant led us to isolation of chelidonine. Chelidonine was tested to determine analgesic effect at a dose of $5 \mathrm{mg} / \mathrm{kg}$, p.o., in mice using tail flick test.

\section{EXPERIMENTAL}

\section{Plant Material}

Chelidonium majus L. was collected in 2003 from flowering plants near Çerkeş-Ankara (Turkey). Voucher specimens were kept in the Herbarium of Ankara University, Faculty of Pharmacy (AEF No. 22918). Taxonomic identy of the plant was confirmed by Prof. Dr. H. Duman a plant taxonomist in the Department of Biological Sciences, Faculty of Art and Science, Gazi University, Ankara, Turkey. 


\section{Test Animals}

The protocol for the study was approved by the Ethical Committee of Yuzuncu Y1l University, Faculty of Medicine. Male Swiss albino mice (22-30 g) were purchased from the Animal House, Yüzüncü Y1l University and Faculty of Medicine. The animals were housed in standard cages $(48 \mathrm{~cm} \times 35 \mathrm{~cm} \times 22 \mathrm{~cm})$ at room temperature $\left(22 \pm 2{ }^{\circ} \mathrm{C}\right)$, with artifical light from 7.00 am to $7.00 \mathrm{pm}$, and provided with pelleted food (Van Animal Feed Factory) and water ad libitum.

\section{Chemicals and Instruments}

Aluminium oxide $\left(\mathrm{GF}_{254}\right.$ Typ E, Merck) was used for chromatotron (Harrison Research, Model 8924, Moana Court, Palo Alto, USA). Precoated aluminium TLC sheets (Silica gel G, 0.25 $\mathrm{mm}$; E-merck) were used for TLC studies. The thin-layer chromatograms were visualized under 254/366 nm UV light (Camag Universal UV Lampe, Germany) and also by spraying with Dragendorff reagent. Melting point was determined with melting point apparatus Büchi SMP-20 (Büchi Labortecknik, Flawil, Switzerland). NMR spectra were run on a Varian Mercury-400, 400 MHz High Performance Digital FT-NMR spectrometer (Varian Inc., Palo Alto, CA, USA), at 400 $\mathrm{mHz}$.

The following drugs were used; Carbon tetrachloride (Merck KgaA, 64271 Darmstadt, Germany), olive oil (Fluka Chemica, Steinheim, Germany) and Aspirin (Bayer, Turkey) that was solubilized in distilled water.

\section{Isolation of Chelidonine}

Aerial parts of Chelidonium majus were extracted with $70 \% \mathrm{EtOH}$ at room temperature. The ethanolic extract was evaporated in vacuum. The concentrated extract was kept in one night at $4{ }^{\circ} \mathrm{C}$. Then the extract was calibrated with $\mathrm{HCl}$ to $\mathrm{pH} 2-3$ and exract was filtered. Petroleum ether extraction was used for removing nonpolar compounds and again the extract was calibrated with $\mathrm{NH}_{4} \mathrm{OH}$ to $\mathrm{pH}$ 8. The residue water phase subjected to solvent-solvent extraction with chloroform and chloroform extract was evaporated to dryness in vacuum for obtaining crude alkaloid extract. The crude extract subjected to Chromatotron. Petroleum ether and chloroform were used for elution. Chelidonine (CM-I) $(5 \mathrm{mg})$ was obtained from fraction 2 (Petroleum ether: Chloroform,9:1).

\section{Characterization of Chelidonine}

Chelidonine was characterized on the basis of its melting point, ${ }^{1} \mathrm{H}-\mathrm{NMR}$ and by comparison with that of the reference standard of Chelidonine (Sigma SLC4915-25MG) 


\section{Analgesic Activity}

Analgesic response was assessed with tail-flick apparatus (LSI Letica LE 7106, Spain) using a method initially described by D'Amour and Smith (10). Six mice were used for each groups tested. The animals were gently immobilized by using a glove, and the radiant heat was focused on a blackened spot 1-2 cm from the tip of the tail. Beam intensity was adjusted to give a tail-flick latency of 5-8 sec in control animals. Measuring was terminated if the latency exceeds the end of time $(15 \mathrm{sec})$ to avoid tissue damage. Mice were tested twice, $30 \mathrm{~min}$ before drug administration in the baseline latency determined and 30,90 and 150 min after drug administration. Chelidonine was administered to the animals at $5 \mathrm{mg} / \mathrm{kg}$ by i.p injection. Aspirin $(100 \mathrm{mg} / \mathrm{kg}$ orally) and morphine hydrochloride (10 $\mathrm{mg} / \mathrm{kg}$ subcutaneously) were used as reference standard. The group with isotonic saline served as the control $(11,12)$.

\section{Statistical Analysis}

All data were represented as mean \pm standard error of mean (SEM). Analysis of variance (ANOVA) was used for the statistical analysis of data. Post-hoc LSD test (least significant difference test) was used for determining significance. Results with $\mathrm{p}<0.05$ were considered as statistically significant.

\section{RESULTS AND DISCUSSION}

For the scientific evaluation of the claimed effects for the aerial parts of Chelidonium majus, we have isolated chelidonine (Figure 1) from the aerial parts of the plant and it was evaluated for its antinociceptive activity using tail-flick test on mice at $5 \mathrm{mg} / \mathrm{kg}$ dose. Results of antinociceptive activity were given in Table 1. Statistical analysis of the data revealed that aspirine and morphine caused significant analgesia at 30th and 90th min compared to isotonic saline solution. Aspirine showed also statistically significant analgesic effect at 150th minute after the administration. Morphine exhibited remarkable antinociceptive activity at $30^{\text {th }}$ and $90^{\text {th }}$ min but only a slight activity was retained at $150^{\text {th }} \mathrm{min}$. Administration of chelidonine $(5 \mathrm{mg} / \mathrm{kg}$, i.p.) produced significant analgesic effect when compared to the controls at 30th, 90th and 150th minutes which was equal to aspirine at $30^{\text {th }}$ and 90th minutes $(p<0.05)$. Whereas chelidonine treatment at $5 \mathrm{mg} / \mathrm{kg}$ dose resulted insignificant increasing in the tail-flick response latency at all time points as compared to the morphine group.

To determine antinociceptive activity of the plant, the aqueous extract of $C$. majus was also investigated for its analgesic effect in mice previously (7). Water extract of C. majus had no 
analgesic effect at 50 and $100 \mathrm{mg} / \mathrm{kg}$ doses. However $200 \mathrm{mg} / \mathrm{kg}$ dose, it produced higher analgesic activity than aspirin at 90th minute. At the 150th minute, its analgesic activity was equal to that of aspirin. In the present study, our results supported the previous findings which suggested that chelidonine is probably responsible from the analgesic activity of this plant. Chelidonine is one of the major alkaloid component of $C$. majus. There are only a few available report about the biological activities of chelidonine which are especially related to its antitumor and cytotoxic activities. It was reported that insignificant tumor inhibition was observed on sarcoma 180 and Erlich carcinoma cells. Furthermore weak cytotoxic activities were observed with chelidonine treatment in HeLa and Erlich carcinoma cell cultures (5). However chelidonine exhibited cytotoxic activity significantly in KB and P388 cell cultures as well as moderately against L-1210, P 388 leukemia and Walker carcinosarkoma (5, 13-14). Semisynthetic N-oxide derivatives of chelidonine, was prepared to enhance activities, which exhibited higher anticancer and bacteriostatic activity than chelidonine. Another derivative of chelidonine is conjugated with thiophosphoric acid, called Ukrain has been reported to have good malignotoxic activity in many cell lines and produced immunostimulant activity in cancer patients $(5,15)$. Chelidonine treatment increased aminotransferase activities in serum of copper-poisoned rats and did not effect the protective changes (16). In England, decoction of this plant or juice gargled have been used to relieve toothache (17). Administration of chelidonine i.p. also exerted inhibitory activity on the central nervous system of the rodents and induced depression the spontaneous and explorative motor activities decreasing body temperature and increasing activity of hypnotic and sedation in reserpinized mice. However it was also reported that chelidonine treatment did not change the activity of mice in hot plate test (18). Our experimental results also revealed that antinociceptive activity of chelidonine did not found to be remarkable when compared to morphine. However similar analgesic activity was observed with aspirine in present study. This may be explained by the fact that although recent studies exerted that hot plate test also allows detecting analgesic compounds such as acetylsalisylic acid, paracetamol, etc., termally induced pain models, tail-flick and hot-plate tests mainly employed to find out the involvement of central analgesics (19). Whereas acetic acid-induced writhing test is considered as an inflammatory visceral pain model (20). This method which is known as nonselective antinociceptive model, has been reported to be useful to investigate the analgesic or anti-inflammatory activities of new substances (21). Results of the present study have clearly demonstrated that the aerial parts of Chelidonium majus posseses significant antinociceptive activity which supports its traditional utilization in Turkey and England. It also could be suggested that analgesic activity of chelidonine probably related to its antiinflammatory effect. However further studies are needed to elucidate the possible mechanism of chelidonine. 
<smiles>CN1Cc2c(ccc3c2OCO3)[C@@H]2[C@@H](O)Cc3cc4c(cc3[C@H]21)OCO4</smiles>

Figure 1. Structure of chelidonine

Table 1. Results of tail-flick tests in Chelidonine, aspirine and *ISS groups

\begin{tabular}{|l|l|l|l|}
\hline \multirow{2}{*}{ Groups } & \multicolumn{2}{|c|}{ Statistical Mean \pm S.E.M. } \\
\cline { 2 - 4 } & $0-30^{\text {th }} \mathrm{min}$ & $0-90^{\text {th }} \mathrm{min}$ & $0-150^{\text {th }}$ min \\
\hline Control & $2.03 \pm 01.45$ & $3.26 \pm 04.26$ & $1.21 \pm 4.98$ \\
\hline Aspirine & ${ }^{\mathrm{a}} 31.75 \pm 04.61$ & ${ }^{\mathrm{a}} 32.43 \pm 07.11$ & ${ }^{\mathrm{a}} 44.30 \pm 4.67$ \\
\hline Morphine & ${ }^{\mathrm{a}} 51.91 \pm 10.57$ & ${ }^{\mathrm{ab}} 74.73 \pm 12.37$ & ${ }^{\mathrm{b}} 0.37 \pm 07.39$ \\
\hline Chelidonine $(5 \mathrm{mg} / \mathrm{kg})$ & ${ }^{\mathrm{a}} 31.52 \pm 11.36$ & ${ }^{\mathrm{ac}} 31.56 \pm 10.80$ & ${ }^{\mathrm{ac}} 37.68 \pm 16.07$ \\
\hline F-value & 7.342 & 10.585 & 6.210 \\
\hline$P$-value & 0.000 & 0.000 & 0.001 \\
\hline
\end{tabular}

*ISS: Isotonic saline solution.

Results of Post-hoc LSD test:

a $P<0.05$ comparison of related group with the control

b $P<0.05$ comparison of related group with the aspirine group

c $P<0.05$ comparison of related group with the morphine group

\section{REFERENCES}

1. Then, M., Szentmihalyi, K., Sarközi, A., Illes, V., Forgacs, E. "Effect of Sample Handling on Alkaloid and mineral Content of aqueous extracts of greater celandine (Chelidonium majus L.)" J. Chromatogr. A, 889, 69-74 (2000).

2. Ciric, A., Vinterhalter, B., Savikin-Fodulovic, K., Sokovic, M., Vinterhalter, D. "Chemical Analysis and Antimicrobial Activity of Methanol Extracts of Celandine (Chelidonium majus L.) Plants Growing in Nature and Cultured In Vitro" Arch. Biol. Sci., 60, 7-8 (2008).

3. Artamonova, E.S., Kurkin, V.A. "Developing Methods For Qualitative and Quantitative Analysis of Chelidonium majus Herbs" Pharm. Chem. J., 42, 633-636 (2008). 
4. Zuo, G.Y., Meng, F.Y., Hao, X.Y., Zhang, Y.L., Wang, G.C., Xu, G.L. "Antibacterial Alkaloids from Chelidonium majus Linn (Papaveraceae) against clinical isolates of methicillin-resistant Staphylococcus aureus" J. Pharm. Pharmaceut. Sci., 11, $90-94$ (2008).

5. Colombo, M.L., Bosisio, E. "Pharmacological Activities of Chelidonium majus L. (Papaveraceae)" Pharmacol. Res., 33, 127-134 (1996).

6. Baytop, T., Therapy with Medicinal Plants in Turkey, Nobel Tip Kitabevleri, İstanbul, p.265-266 (1999).

7. Yılmaz Sever, B., Özbek, H., Saltan Çitoğlu, G., Uğraş, S., Bayram, İ., Erdoğan, E. "Analgesic and Hepatoprotective Effects of Chelidonium majus L." J. Fac. Pharm., Ankara, 36, 9-20 (2007).

8. Lee, Y., Kim, S., Roh, S., Choi, H., Seo, Y. "Suppressive effects of Chelidonium majus methanol extract in knee joint, regional lymph nodes, and spleen on collagen-induced arthritis in mice" J. Ethnopharmacol., 112, 40-48 (2007).

9. Chung, H., An, H., Jeong, H., Won, J., Hong, S., Kim, H. "Water extract isolated from Chelidonium majus enhances nitric oxide and tumor necrosis factor- $\alpha$ production via nuclear factor ${ }_{\mathrm{K}} \mathrm{B}$ activation in mouse peritoneal macrophages" J. Pharm. Pharmacol., 56, 129-134 (2004).

10. D'Amour, F.E., Smith, D.L. "A method for determining loss of pain sensation" $J$. Pharmacol. Exp. Ther., 72, 74-76 (1941).

11. Dewan, S., Sangraula, H., Kumar, V.L. "Preliminary studies on the analgesic activity of latex of Calotropris procera" J. Ethnopharmacol., 73, 307-311 (2000).

12. Matsumoto, K., Horie, S., Ishikawa, H., Takayama, H., Aimi, N., Ponglux, D., Watanabe, K. "Antinociceptive effect of 7-hydroxymitragynine in mice: Discovery of an orally active opioid analgesic from the Thai medicinal herb Mitragyna speciosa" Life Sci., 74, 2143-2155 (2004).

13. Sağlam, H., Arar, G. "Cytotoxic activity and quality control determinations on Chelidonium majus" Fitoterapia, 74, 127-129 (2003).

14. Kemény-Beke, A., Aradi, J., Damjanovich, J., Beck, Z., Facskó, A., Berta, A., Bodnár, A. "Apoptotic response of uveal melanoma cells upon treatment with chelidonine, sanguinarine and chelerythrine" Cancer Lett., 237, 67-75 (2006). 
15. Jalilian, A.R., Seyfi, P., Afarideh, H., Shafiee, A. "Synthesis of a $\left[{ }^{18} \mathrm{~F}\right]$ labeled chelidonine derivative as a possible antitumor agent" Appl. Radiat. Isotopes,54, 407-411 (2001).

16. Jagiello-Wojtowicz, E., Izdebska, M., Piatkowska-Chmiel, I. "Effects of chelidonine and ukrain on the activity of serum ALT and AST in rats intoxicated by copper chloride" Herba Pol., 48, 274-277 (2002).

17. Lewis, W.H., "Plants Affecting Human Health" in Medical Botany, John Wiley and Sons, New Jersey, 419 (2003).

18. Jagiello-Wojtowicz, E., Jusiak, L., Szponar, J., Kleinrok, Z. "Preliminary pharmacological evaluation of chelidonine in rodents" Pol. J. Pharmacol. Pharm., 41, 125131 (1989).

19. Mazzanti, G., Di Sotto, A., Franchitto, A., Mammola, C.L., Mariani, P., Mastrangelo, S., Menniti-Ippolito, F., Vitalone, A. "Chelidonium majus is not hepatotoxic in Wistar rats, in a 4 weeks feeding experiment" J. Ethnopharmacol., 126, 518-524 (2009).

20. Devi, R.A., Tandan, S.K., Kumar, D., Dudhgaonkar, S.P., Lal, J. "Analgesic activity of Caesalpinia bonducella flower extract" Pharm. Biol., 46(10-11), 668-672 (2008).

21. Nonato, F.R., Barros, T.A.A., Lucchese, A.M., Oliveira, C.E.C., Santos, R.R., Soares, M.B.P., Villarreal, C.F. "Antiinflammatory and antinociceptive activities of Blechnum occidentale L. Extract" J. Ethnopharmacol. 125, 102-107 (2009). 